\title{
Neuroprotection by Therapeutic Hypothermia
}

\author{
Ying-Jian Sun, Zi-Yuan Zhang, Bin Fan and Guang-Yu Li* \\ Department of Ophthalmology, The Second Hospital of Jilin University, Changchun, China
}

Hypothermia therapy is an old and important method of neuroprotection. Until now, many neurological diseases such as stroke, traumatic brain injury, intracranial pressure elevation, subarachnoid hemorrhage, spinal cord injury, hepatic encephalopathy, and neonatal peripartum encephalopathy have proven to be suppressed by therapeutic hypothermia. Beneficial effects of therapeutic hypothermia have also been discovered, and progress has been made toward improving the benefits of therapeutic hypothermia further through combination with other neuroprotective treatments and by probing the mechanism of hypothermia neuroprotection. In this review, we compare different hypothermia induction methods and provide a summarized account of the synergistic effect of hypothermia therapy with other neuroprotective treatments, along with an overview of hypothermia neuroprotection mechanisms and cold/hypothermiainduced proteins.

National Institute of Neurology and Neurosurgery (INNN), Mexico

Reviewed by:

Carmen Rubio,

National Institute of Neurology and Neurosurgery (INNN), Mexico

Rosalia Mendez-Otero,

Federal University of Rio de Janeiro,

Brazil

Francisca Pérez-Severiano,

National Institute of Neurology and Neurosurgery (INNN), Mexico

*Correspondence: Guang-Yu Li gy.li@yahoo.com

Specialty section: This article was submitted to

Neurodegeneration, a section of the journal Frontiers in Neuroscience

Received: 23 February 2019 Accepted: 23 May 2019

Published: 11 June 2019

Citation:

Sun Y-J, Zhang Z-Y, Fan B and Li G-Y (2019) Neuroprotection by

Therapeutic Hypothermia.

Front. Neurosci. 13:586.

doi: 10.3389/fnins.2019.00586

\section{INTRODUCTION}

A number of experimental and clinical studies have provided evidence in support of the neuroprotective effects of induction of hypothermia. The earliest recording of hypothermia as a therapeutic agent is dated more than 5000 years old, coming from an ancient Egyptian Edwin Smith Papyrus (Wang et al., 2006). In ancient times, hypothermia therapy consisting of ice packs was used to treat hemorrhage, and said therapy was also widely used in cardiac arrest (Dzieciol et al., 2014), comatose patients (Dell'Anna et al., 2014) and other diseases. There was an apparent interest in the exploration of the mechanism(s) of hypothermia neuroprotection. A role of hypothermia has now been reported in many neurological diseases, for instance, stroke, traumatic brain injury, intracranial pressure elevation, subarachnoid hemorrhage, spinal cord injury, hepatic encephalopathy, and neonatal peripartum encephalopathy (Karnatovskaia et al., 2014). However, it has also been reported that hypothermia may not be neuroprotective (Clifton et al., 2001; Hutchison et al., 2008; Maekawa et al., 2015). Such discrepancies in literature might perhaps be related to the duration of cooling time and the methods used to induce hypothermia (Clifton et al., 2001; Hutchison et al., 2008; Wowk et al., 2014; Maekawa et al., 2015). The methods employed to induce hypothermia have profound effect on the resulting neuroprotection. Combination with other treatment methods has been explored as a means to enhance the benefits of hypothermia protection. Even after several reports on the topic, the mechanisms, by which hypothermia affords neuroprotection, remain unclear. It is believed that hypothermia-induced neuroprotection might be due to decreased metabolism, reduced generation of radicals, ameliorated inflammation and inhibition of excitotoxicity and apoptosis. Further, the importance of cold-induced proteins as important components of hypothermia neuroprotection has also been realized. In this review, we have summarized methods of hypothermia induction, and the effectiveness of combination of 
other neuroprotective methods with hypothermia and the cold-induced proteins. We hope that this article will provide guidance for future pre-clinical studies and the clinical trials on hypothermia neuroprotection.

\section{HYPOTHERMIA INDUCTION METHODS}

Experimental as well as clinical data points to a proven neuroprotective effect of therapeutic hypothermia. Also, hypothermia induction methods have an influence on the hypothermia effect. The two most commonly used methods for induction of hypothermia are local hypothermia and general hypothermia.

Local hypothermia provides precise hypothermic regions in the damaged area and the rectal temperature is kept $34-35^{\circ} \mathrm{C}$ to minimize the potential side effects of hypothermia. Many physical methods are used to achieve local hypothermia, for example, a cooling helmet is a good way to achieve rapid and selective brain hypothermia for a stroke or head injury patient (Wang et al., 2004; Ikeda et al., 2012). In a research study comprising of 15 patients following resuscitation, selective head cooling by a cooling helmet decreased urinary 8 -OHdG levels on days 6 and 7 (Ikeda et al., 2012). Bennet et al. (2007) used a cooling coil made from silicone tubing in a severe hypoxia model of preterm fetal sheep for local hypothermia and observed reduced loss of neurons and immature oligodendroglia. In a study on spinal cord injury research (Bazley et al., 2014), the system included a heat exchanger constructed from copper tubing, bent into four layers that were all equal in length, measuring $4.4 \times 0.8$ inches each, and the tubing was inserted under the skin over the paravertebral muscle extending from the T6 to T10 spinal segments. By circulating cold water, local hypothermia was achieved and was found to be beneficial for spinal cord injury.

In general therapy, a $33-34^{\circ} \mathrm{C}$ rectal temperature is maintained, creating a moderate systemic hypothermia (Shankaran et al., 2005; Azzopardi et al., 2008; Jacobs et al., 2011). Further, for general hypothermia, two approaches commonly used are physical hypothermia and pharmacological hypothermia. Reducing ambient temperature, using a cooling blanket or ice pad and infusing rapidly cooled saline are considered physical hypothermia (Ikeda et al., 2012). Pharmacological hypothermia is related to drugs such as the neurotensin (NT) (Zhang et al., 2013). Gu et al. (2015) revealed the potential therapeutic effects on stroke and traumatic brain injury of adult rodents of Neurotensin receptor-1 (NTR1) agonist HPI201 (formerly known as ABS201)-induced hypothermia. HPI201-induced hypothermia resulted in markedly reduced MMP-9 levels and caspase-3 activation. NTR1 agonist induced hypothermia via the NTR receptor in the brain (Dubuc et al., 1999). Hwan et al. (2014) demonstrated that HPI-363 is approximately 10 times more potent than HPI-201 in inducing therapeutic hypothermia. HPI-363 is the analog of NT (8-13). This is because of the C-terminal hexapeptide that has structural elements critical for complete biological activity (Carraway and Leeman, 1975). The biologically stable NT (8-13) analogs can penetrate the blood-brain barrier (Kokko et al., 2005), while original NTR1 agonists cannot. Anesthetic is another method used to induce hypothermia (Whittington et al., 2013). It has been reported that isoflurane-induced hypothermia attenuates the early phase blood-brain barrier disruption in cerebral ischemia (Liu et al., 2017). N-cyclohexyladenosine (CHA), an $\mathrm{A}_{1}$ adenosine receptor $\left(A_{1} A R\right)$ agonist, also induced hypothermia, and animals subjected to cardiac arrest and cooled by CHA survived better and exhibited less neuronal cell death (Jinka et al., 2015). Further, the agonist of transient receptor potential vanilloid channel 1 (TRPV1), dihydrocapsaicin (DHC), is used in pharmacological hypothermia as well (Zhang J. et al., 2018). Compared with pharmacological cooling processes, physical cooling processes are costly and time-consuming (Alexander et al., 2012). It may be because of shivering, a defensive metabolic response to cold, that works against temperature reduction. Therefore, anesthesia has to be used in patients to combat the cold defense response, which has the potential to lead to infection and possibly other side effects due to prolonged hypothermia (Schwab et al., 1998), while NTR compounds lead to a lack of shivering ( $\mathrm{Gu}$ et al., 2015). Also, physical cooling has associated complications such as hypotension, arrhythmia and change of fluid pH (Gröger et al., 2013; Mohr et al., 2013; Stuart et al., 2013). It seems that pharmacological reagent-induced controlled hypothermia, which targets the brain thermoregulatory center, has emerged as an efficient and considerably safer treatment for patients, with a further benefit being that a lot of choices of drug are provided. Zhang et al. (2013) reviewed the neuroprotective effects of eight classes of hypothermia-inducing drugs: the cannabinoids, opioid receptor activators, transient receptor potential vanilloid, neurotensins, thyroxine derivatives, dopamine receptor activators, hypothermia-inducing gasses, adenosine and adenine nucleotides. However, pharmacological intervention still has its limitations. Just like NT (8-13) analogs, the drugs caused severe hypothermia ( $<30$ degrees) leading to the requirement for more significant re-warming measures (Tyler-McMahon et al., 2000a,b; Katz et al., 2004; Smith et al., 2011). Drugs also have the associated problem of drug resistance and hypothermic tolerance. Every drug application may disturb the balance of whole body such as the metabolic and cardiovascular systems (Piehl et al., 2011), in addition to the face that each person has individual differences in the drug dose they require. Moreover, it has been demonstrated that the combination of low DHC and ice pads significantly improves every measured outcome, compared to low DHC or the ice pad alone. Combination therapy achieved hypothermia faster; reduced more neurological deficits and decreased apoptotic cell death (Zhang J. et al., 2018). Barks et al. (2010) found that the combination therapy sustained more benefits in late outcome assessment of cerebral hypoxia-ischemia. These observations clearly indicate that combining physical and pharmacological hypothermia could be a promising therapy (Figure 1).

In addition, some comparisons were made between general hypothermia and local hypothermia. In a global ischemia research study, a water-cooling blanket (the rapid infusion of cooled saline, gastric lavage with cooled saline) and sedation were used to cool the whole body. Head cooling was achieved by a cooling helmet. These two neuroprotections 


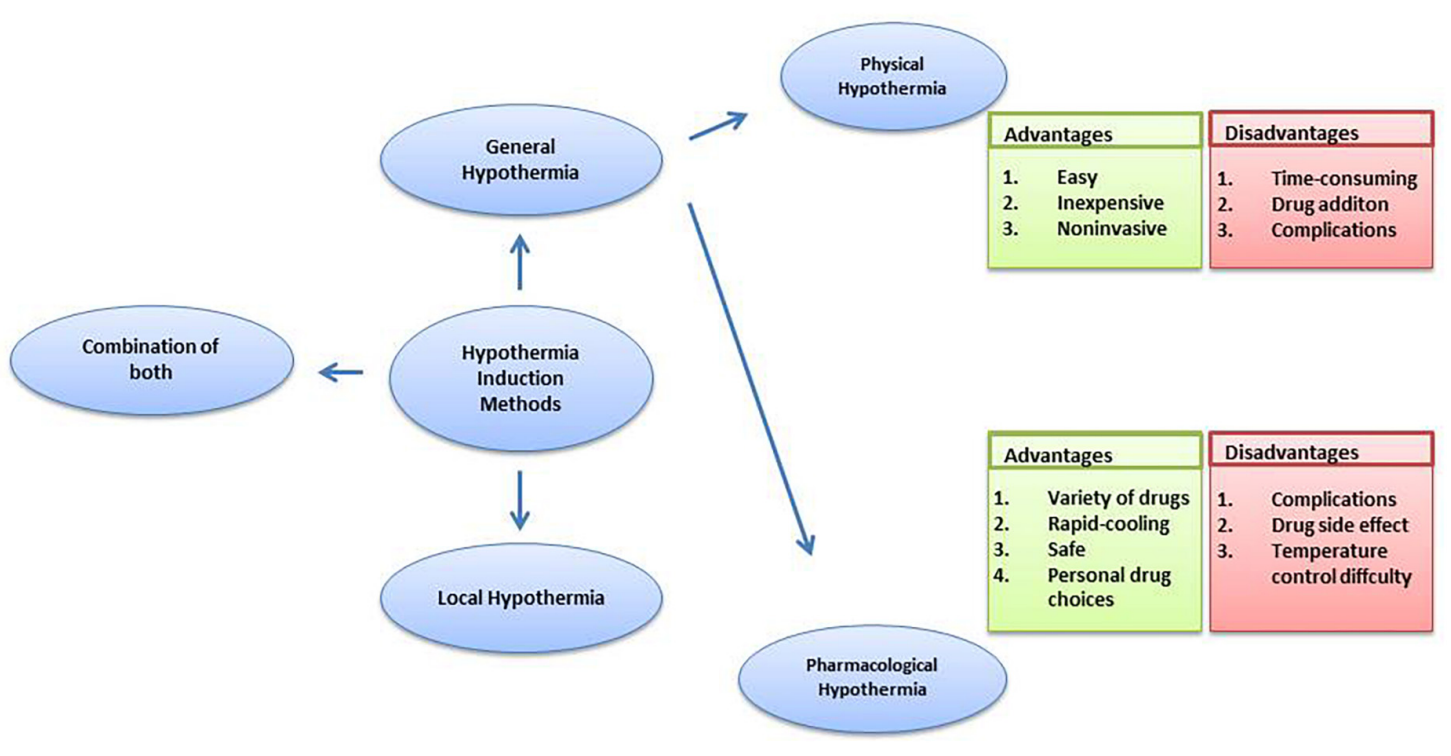

FIGURE 1 | The comparison of hypothermia induction methods.

are similar, and whole-body cooling had a greater effect on the suppression of radical production than head cooling (Ikeda et al., 2012). A research study comparing selective head cooling therapy with whole body cooling therapy in newborns with hypoxic ischemic encephalopathy uncovered no difference between the two methods in terms of adverse effects and short-term results (Atici et al., 2015). Other research studies have also reached similar conclusion about hypoxic ischemic encephalopathy (Sarkar et al., 2009a,b; Celik et al., 2016). However, it was reported that local hypothermia is better than general hypothermia with a significantly lower rate of severe cortex lesions (Rutherford et al., 2005). It has been reported that local hypothermia may be more suitable for longer durations of hypothermia treatment for spinal cord injury because it does not require as much temperature change in healthy tissues (Bazley et al., 2014). In conclusion, local hypothermia may be the best option for providing similar protection to general hypothermia and reducing temperature effects throughout the body, along with minimizing side effects. Further studies are still necessary to compare the adverse effects between local and general hypothermia and reach a definitive conclusion.

\section{HYPOTHERMIA COMBINED WITH OTHER NEUROPROTECTIVE METHODS}

In addition to hypothermia neuroprotection, there are other treatments that are applied to nerve injury. However, the combination of hypothermia and other treatments was found to produce a greater neuroprotective effect. These therapies are divided into three categories: cell therapy (Table 1), drug therapy (Table 2), and other therapies (Table 3).

For cell therapy, stem cells are differentiated into a variety of cells within the nervous system in order to be used for the treatment of nerve diseases. Wang and coworkers found that combination treatment with therapeutic hypothermia produced synergistic effects in transplantation to promote the recovery of spinal cord injury (Wang D. et al., 2014; Zhu et al., 2015), while in hypoxic-ischemic encephalopathy, it was found to exert simple

TABLE 1 | The combination of hypothermia and cell therapy.

\begin{tabular}{|c|c|c|c|}
\hline Combination strategy & Model & Diseases & References \\
\hline Neural stem cells transplantation & Spinal cord injury rat model & Spinal cord injury & Zhu et al., 2015 \\
\hline $\begin{array}{l}\text { Cell-scaffold complex seeded with Nogo receptor } \\
\text { (NgR)-silenced neural stem cells and Schwann cells } \\
\text { transplantation }\end{array}$ & Spinal cord injury rat model & Spinal cord injury & Wang D. et al., 2014 \\
\hline Neural stem cells transplantation & Carotid artery ligation rat model & $\begin{array}{l}\text { Hypoxic-ischemic } \\
\text { encephalopathy }\end{array}$ & Wang L. et al., 2014 \\
\hline Mesenchymal stem cells transplantation & Carotid artery ligation rat model & $\begin{array}{l}\text { Hypoxic-ischemic } \\
\text { encephalopathy }\end{array}$ & Park et al., 2015 \\
\hline Mesenchymal stem cells transplantation & Lateral fluid percussion brain injury rat model & Traumatic brain injury & Tu et al., 2012 \\
\hline Adipose-derived stem cells transplantation & Middle cerebral artery occlusion (MCAO) rat model & Stroke & Zhao et al., 2018 \\
\hline
\end{tabular}


TABLE 2 | The combination of hypothermia and drug therapy.

\begin{tabular}{|c|c|c|c|}
\hline Combination strategy & Model & Diseases & References \\
\hline i.v. $1 \mathrm{mg} / \mathrm{kg}(0.2 \mathrm{~m} \mathrm{~L} / \mathrm{kg})$ of Cannabidiol & Carotid artery ligation rat model & Hypoxic-ischemic encephalopathy & Lafuente et al., 2016 \\
\hline i.p. $2.5 \mathrm{mg} / \mathrm{kg}$ of bumetanide & Carotid artery ligation rat model & Hypoxic-ischemic encephalopathy & Liu et al., 2012 \\
\hline $\begin{array}{l}\text { i.p. } 0.05 \mathrm{ml} / 10 \mathrm{gm} \text { of Docosahexaenoic } \\
\text { Acid (DHA) }\end{array}$ & Carotid artery ligation rat model & Hypoxic-ischemic encephalopathy & Berman et al., 2013 \\
\hline $\begin{array}{l}\text { i.v. } 0.0016 \text { PNAU/100 g human urinary } \\
\text { kallidinogenase }\end{array}$ & Carotid artery ligation rat model & Hypoxic-ischemic encephalopathy & Gao et al., 2018 \\
\hline i.p. 40 mg/kg of phenobarbital & Carotid artery ligation rat model & Hypoxic-ischemic encephalopathy & Barks et al., 2010 \\
\hline p.o. 0.5 mg/g exendin-4 & Carotid artery ligation mouse model & Hypoxic-ischemic encephalopathy & Rocha-Ferreira et al., 2018 \\
\hline $\begin{array}{l}\text { i.p. } 20 \mathrm{mg} / \mathrm{kg} \text { of topiramate or } \\
\text { memantine/ } 0.01-1 \mu \mathrm{M} \text { topiramate and } \\
1-30 \mu \mathrm{M} \text { memantine }\end{array}$ & $\begin{array}{l}\text { Carotid artery ligation rat } \\
\text { model/OGD organotypic } \\
\text { hippocampal slice model }\end{array}$ & Hypoxic-ischemic encephalopathy & Rocha-Ferreira et al., 2018 \\
\hline i.v. 200 IU/kg of erythropoietin & Clinical patients & Hypoxic-ischemic encephalopathy & Lv et al., 2017 \\
\hline s.c. $15 \mathrm{mg} / \mathrm{kg}$ of G-CSF & MCAO rat model & Stroke & Ghahari et al., 2014 \\
\hline p.o. $1 \mathrm{mg} / \mathrm{kg}$ of atorvastatin & MCAO rat model & Stroke & Lee et al., 2008 \\
\hline i.p. 10 mg/kg of HPI 201 & MCAO rat model & Stroke & Lee et al., 2016 \\
\hline $\begin{array}{l}\text { i.v. } 1 \mathrm{mg} / \mathrm{kg} \text { of chlorpromazine and } \\
1 \mathrm{mg} / \mathrm{kg} \text { of promethazine }\end{array}$ & MCAO rat model & Stroke & Liu S. et al., 2015 \\
\hline i.v. 300 mg/kg of valproic acid & Cardiac arrest rat model & Cardiac arrest & Oh et al., 2017 \\
\hline $\begin{array}{l}\text { i.v. } 4 \mathrm{ml} / \mathrm{kg} \text { of Emulsified isoflurane } \\
\text { (Elso) }\end{array}$ & Cardiac arrest rat model & Cardiac arrest & Wu et al., 2017 \\
\hline i.v. $3 \mathrm{mg} / \mathrm{kg}$ of tacrolimus & $\begin{array}{l}\text { Lateral fluid percussion brain injury } \\
\text { rat model }\end{array}$ & Traumatic brain injury & Oda et al., 2011 \\
\hline $1 \mathrm{mmol} / \mathrm{L}$ VPA & $\begin{array}{l}\text { Cobalt chloride }\left(\mathrm{Co}_{2}\right) \text { induced } \\
\text {-hypoxia cell model }\end{array}$ & $\begin{array}{l}\text { Cerebral ischemic and traumatic } \\
\text { brain injury. }\end{array}$ & Jin et al., 2014 \\
\hline i.p. 400 mg/kg of citicoline & MCAO rat model & Cerebral ischemic & Sahin et al., 2010 \\
\hline Infusion, 5 mg/kg of melatonin & Perinatal asphyxia piglet model & Hypoxic-ischemic encephalopathy & $\begin{array}{l}\text { Powell et al., 2011; } \\
\text { Robertson et al., } 2013\end{array}$ \\
\hline Infusion, 1 mg/kg HET0016 & Asphyxia piglet model & Hypoxic-ischemic encephalopathy & Zhu et al., 2015 \\
\hline $40 \mu \mathrm{M}$ dantrolene & OGD/R cell model & Stroke & Xu et al., 2015 \\
\hline 100 nM C5a RA & OGD/R cell model & Stroke & Thundyil et al., 2012 \\
\hline
\end{tabular}

neuroprotective effects (Wang L. et al., 2014). On neonatal hypoxia-ischemic encephalopathy, mesenchymal stem cells transplantation combined treatment with hypothermia proved to be a better therapy than either therapy alone (Park et al., 2015). Furthermore, the temperature-sensitive mesenchymal stem cells from an umbilical cord, infected with a retrovirus carrying the temperature-sensitive A58 SV40 LT antigen gene, were applied to the traumatic brain injury. In this study, the greatest protective effect on the recovery of neurological function was the therapy which combined temperature-sensitive mesenchymal stem cells and hypothermia (Tu et al., 2012). Additionally, for treating stroke, adipose-derived stem cells combined with hypothermia produced a superior approach (Zhao et al., 2018). Moreover, many drugs enhanced therapeutic hypothermia neuroprotection in nerve injury. They included chemical drugs, hormones, neuroprotectants and others. For example, valproic acid is a histone deacetylase inhibitor. Jin et al. (2014) showed that the combined treatment with valproic acid and hypothermia improves survival and decreases cell death after chemically induced hypoxia in HT22 hippocampal cells. Valproic acid also enhanced neuroprotective effect of hypothermia against ethanol-mediated neuronal injury, and improved survival in a rat cardiac arrest model (Oh et al., 2017; Vishwakarma et al., 2017).
Bumetanide, a clinically available loop diuretic, inhibited NKCC1 and improved the neuroprotective efficacy of treatment with phenobarbital and hypothermia in a neonatal cerebral hypoxiaischemia model (Liu et al., 2012). Cannabidiol (CBD), the main non-psychoactive component of Cannabis sativa, has recently been shown to produce additive effect with hypothermia, resulting in a greater overall benefit in the early $\mathrm{HI}$ brain damage (Lafuente et al., 2016). Combined emulsified isoflurane and hypothermia treatment results in significant improvements in survival and neurological outcomes in a rat model of cardiac arrest (Wu et al., 2017). Dantrolene enhances the protective effect of hypothermia on OGH/R cerebral cortex neurons (Xu et al., 2015). Early post-hypoxia-ischemia administration of phenobarbital may augment the neuroprotective efficacy of therapeutic hypothermia (Barks et al., 2010) and some hormones have a neuroprotective effect in augmenting hypothermia protection. Melatonin augmented hypothermic neuroprotection in a piglet model of perinatal asphyxia (Powell et al., 2011). Exendin-4 is an analog of the human glucagon-like peptide-1 (GLP-1) gut hormone peptide. In a study by Rocha-Ferreira et al. (2018), exendin-4 was found to enhance the neuroprotection of therapeutic hypothermia. The combined therapy with human urinary kallidinogenase (HUK) and hypothermia enhanced 
the efficiency by promoting angiogenesis and regeneration and rescuing tight-junction loss in HIE rat model (Gao et al., 2018). And for erythropoietin, no significant benefit was observed from treatment with combination therapy in HIE rat experiments (Fang et al., 2013). However, erythropoietin combined with hypothermia reduced serum Tau protein levels and improved neonatal behavioral neurology outcomes but did not affect long-term neurodevelopmental outcomes in neonatal patients (Lv et al., 2017). Neuroprotectants, such as G-CSF, were used in brain injury. Hypothermic treatment plus G-CSF significantly reduced mortality rate and edema and improved neurological function in the rat transient middle cerebral artery occlusion (MCAO) model (Ghahari et al., 2014). Atorvastatin enhances hypothermia-induced neuroprotection after stroke (Lee et al., 2008). And in a study by Gao et al. (2014), a series of neuroprotectants including albumin, atorvastatin, baclofen, brain-derived neurotrophic factor, bumetanide, citicoline sodium salt hydrate, cyclosporine A etc., were applied to a oxygen-glucose deprivation and re-oxygenation-mediated neuronal injury. This research showed that combination of therapeutic hypothermia with brain derived neurotrophic factor, glibenclamide, dizocilpine, HUK or neuroglobin provided a better protection compared with a single treatment method. There are some other drugs like chlorpromazine, promethazine, citicoline and HET0016, which also augment therapeutic hypothermia protection (Sahin et al., 2010; Liu S. et al., 2015; Zhu et al., 2015). Furthermore, xenon, $\mathrm{MgSO}_{4}$ and Chinese traditional bloodletting treatment also offered better neuroprotection when combined with hypothermia (Ma et al., 2005; Zhu et al., 2005; Tu et al., 2016).

Most of these combined treatments are confirmed to be more effective than any other treatment being used alone. They can play their therapeutic role via many ways, such as scavenging free radicals, reducing energy consumption, reducing excitotoxicity and so on (Zhang Z. et al., 2018). However, there is no denying that some combined treatments did not exhibit a synergistic effect, such as that argon augmented therapeutic hypothermia which does not improve functional recovery in cardiac arrest, but may even worsen neurologic function. These findings suggest that future studies are warranted to investigate more specific mechanisms and modulating factors in neuroprotection.

\section{MECHANISMS OF HYPOTHERMIA-MEDIATED PROTECTION}

Therapeutic hypothermia is a promising neuroprotective intervention which has been shown to improve outcomes from nerve injury in humans. The neuroprotective role of hypothermia has been well established in experimental animals and in patients with cardiac arrest (Hakim et al., 2018), hypoxic-ischemic encephalopathy (Yum et al., 2018), traumatic brain injury (Leng, 2017) and other diseases (Zhu et al., 2015). Although the neuroprotective mechanisms of hypothermia in different diseases vary and have yet to be fully determined, the neuroprotection has been commonly ascribe to its effect on decreasing the metabolic rate, reducing the generation of radicals, ameliorating inflammation, inhibiting excitotoxicity and apoptosis.

Hypothermia decreases the metabolic rate of neurons after spinal cord injury, traumatic brain injury and other diseases. Metabolic changes associated with hypothermia include preserving glucose (Schaller and Graf, 2003), inhibited lactate generation (Drenger et al., 1997), increased plasma levels of glycerol (Wang et al., 2007), free fatty acids and ketoacids (Aoki et al., 1993). These metabolic changes induced by hypothermia are beneficial to preservation of $\mathrm{pH}$ and ATP of tissue and cell which promotes homeostasis (Kuffler, 2010).

The generation of free radicals and nitric oxide is considered to be associated with neuron damage (Lewen et al., 2000). Hypothermia, however, significantly inhibits superoxide and lipid peroxidation to decrease the generation of free radicals. Hypothermia was found to decrease the levels of ROS induced by ischemic stroke (Gao et al., 2014) and suppress the elevation in internal jugular NO after cerebral ischemia-reperfusion (Kumura et al., 1996).

Inflammation is involved in the occurrence and development of diseases, such as, cerebral ischemic injury. Further, hypothermia modulates inflammatory factors to reduce the inflammatory response. In acute brain injury, complement activation stimulates neutrophil pathways. Pro-inflammatory cytokines, including IL-1 $\beta$, IL-6, IL-18, and TNF, are increased, which exacerbate neuronal injury (Huang et al., 2006; Nilupul Perera et al., 2006). Hypothermia has been shown to decrease the pro-inflammatory cytokines and increase anti-inflammatory cytokines production to inhibit inflammatory response (Vitkovic et al., 2001; Yatsiv et al., 2002; Hofstetter et al., 2007). However, anti-inflammatory cytokines such as IL-10 can also be reduced by hypothermia (Huet et al., 2007). It, therefore, appears that hypothermia may have a complex role in inflammatory modulation to protect neurons, that still needs to be elucidated.

Hypothermia also provides a neuroprotective benefit by decreasing excitotoxicity. The accumulation of excitotoxic amino acids, such as glutamate, is proven important in the pathogenesis of neuron damage (Dumont et al., 2001; Colbourne et al., 2003; Park et al., 2004; Sahuquillo and Vilalta, 2007; Mazzone and Nistri, 2011). It has been reported that hypothermia inhibits the release of glutamate in a rat spinal cord ischemia model (Ishikawa and Marsala, 1999). Globus et al. (1995) demonstrated that hypothermia reduces the extent of neuronal damage in traumatic brain injury by decreasing excessive extracellular release of glutamate and generation of hydroxyl radicals. Hypothermia reduced the release of glutamate by down-regulating the AMPA ( $\alpha$-amino-3-hydroxy-5-methy1-4-isoxazole-propinoic acid) to limit calcium influx and up-regulating the human glial glutamate transporter (hGLT-1).

In addition to the above mechanisms, hypothermia also works by inhibiting neuron cell apoptosis. Mild hypothermia can interfere with the intrinsic and extrinsic cell apoptosis. Intrinsic cell apoptosis is associated with caspase family of apoptosis mediators. Neuron cell injury signals promote translocation of pro-apoptotic protein Bax and Bid from cytosol to the mitochondrial membrane changing the 
TABLE 3 | The combination of hypothermia and other therapies.

\begin{tabular}{lll}
\hline Combination strategy & Model & Diseases \\
\hline Xenon & Carotid artery ligation rat model/OGD cell model & Hypoxic-ischemic encephalopathy \\
Intravenous loading dose of & 2 vessel occlusion with hypotension rat model & Stroke
\end{tabular}

$360 \mu \mathrm{mol} / \mathrm{kg} \mathrm{MgSO}_{4}$ before

ischemia followed by intravenous

infusion (IVI) at $120 \mu \mathrm{mol} / \mathrm{kg}$

Bloodletting at Jing points

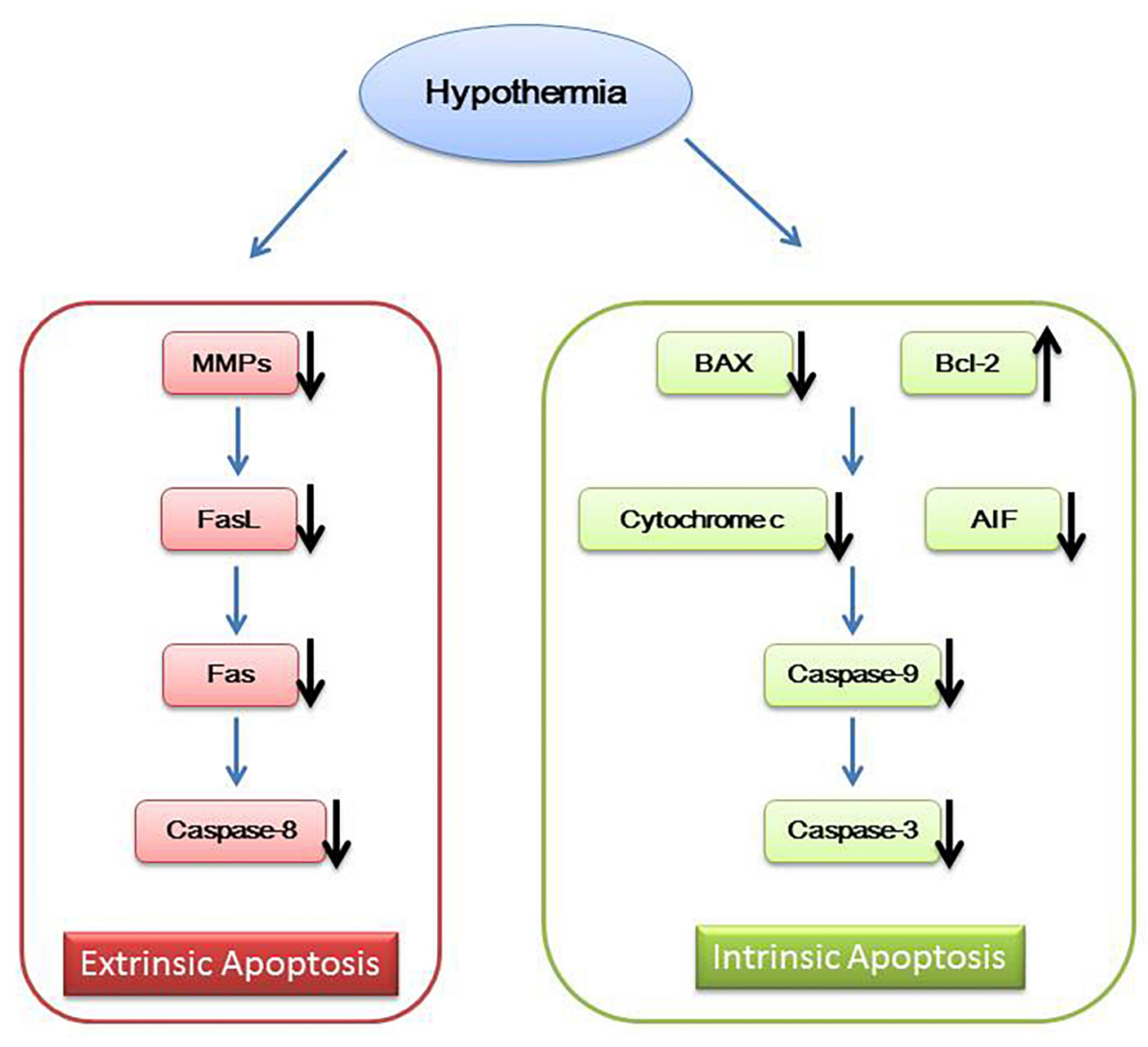

FIGURE 2 | Hypothermia and apoptosis.

mitochondrial membrane potential and releasing cytochrome-c and apoptosis inducing factor (AIF) (Plesnila et al., 2001; Yenari et al., 2002; Shamas-Din et al., 2011). Then, cytochrome-c activates caspase-9 and caspase-3, leading to cell apoptosis (Zhu et al., 2004; Ohmura et al., 2005; Ok et al., 2012). Extrinsic cell apoptosis is mediated by Fas/FasL. Increased Fas activates caspase-8, resulting in cell apoptosis (Liu et al., 2008; Ehrenschwender and Wajant, 2009). Mild hypothermia increases $\mathrm{Bcl}-2$, reduces cytochrome c release, inhibits the expression of BAX and decreases caspase family members such as caspase-9, caspase-8, and caspase-3 (Zhu et al., 2004; Ohmura et al., 2005; Ok et al., 2012; Sun et al., 2019). Mild hypothermia also inhibits the expression of matrix metalloproteinases (MMPs) to affect FasL (Lee et al., 2005), eventually leading to reduced Fas and caspase- 8 (Liu et al., 2008; Figure 2).

\section{COLD INDUCED PROTEIN}

Although the key mechanisms have not been established clearly, cold induced proteins may play a key role in hypothermia neuroprotection, which suggests their targeting as novel therapeutic drug targets. Plenty of studies have uncovered a neuroprotective effect, focusing on these proteins. Cold-inducible RNA-binding protein (Cirbp) and cold-inducible RNA-binding protein motif 3 (RBM3) are the most widely studied proteins in this respect.

Cirbp, discovered in 1997, is a RNA-binding factor composed of a N-terminal RNA Recognition Motif (RRM) and a C-terminal region containing several repeats of the RGG motif (Zhu et al., 2016a). This protein is detected in lowlevel expression in human pancreas, heart, thyroid and other cells (Nishiyama et al., 1997). Xue et al. (1999) detected the 
expression of this protein in brains, lungs, stomachs and spinal cords of rats. When the temperature drops, expression levels of Cirbp are increased in PC12, K562, NC65 and other cell lines, and the expression of Cirbp in cells is decreased when the temperature is increased. Besides, in TNF- $\alpha$-induced mouse fibroblast cells, hypothermia inhibited the apoptosis, and Cirbp levels were increased (Sakurai et al., 2006). Further, overexpression of Cirbp or application of recombinant Cirbp have shown protection against cell apoptosis (Liu J. L. et al., 2015; Wang and Zhang, 2015). In addition, knocking down Cirbp, with shRNA-Cirbp, blocked neuroprotection under hypothermic conditions in $\mathrm{H}_{2} \mathrm{O}_{2}$-induced apoptosis and caspase-dependent neuron apoptosis (Liu et al., 2012; Wang and Zhang, 2015). All these observations reveal that Cirbp is involved in the protection of tissues and organs by hypothermia. The RRM and repeats of RGG motif enhance binding of Cirbp to the 3' UTR of TRX mRNA, resulting in enhanced expression of TRX in cells (Yokomizo et al., 1995). TRX is a well-known ROS scavenger (Park et al., 1999; Sahara et al., 2002), and Since ROS plays a crucial role in initiating caspase-dependent pathways through induction of TRX, Cirbp may suppress intrinsic cell death mainly through TRX. Furthermore, it has been demonstrated that caspase-dependent apoptosis protein Bax, caspase- 3 and caspase- 9 are inhibited, and anti-apoptotic protein $\mathrm{Bcl}-2$ upregulated in the rat brain cortex neurons, through upregulation of Cirbp (Wang and Zhang, 2015). Xia et al. (2013) uncovered that Bcl-2 was upregulated and Cirbp was overexpressed in BALB/c mouse testicles. Also, cirbp inhibits DNA damage-induced apoptosis by downregulating caspase-3 (Lee et al., 2015). These studies indicate Cirbp to be a regulator of caspase-dependent apoptosis pathway, in which overexpression of Cirbp can downregulate caspase-3 and other apoptosisrelated proteins, while knockdown of Cirbp exacerbates these proteins expression. In addition, the level of phosphorylated extracellular signal-regulated kinase1/2 (ERK1/2) upregulation was observed in $\mathrm{H}_{2} \mathrm{O}_{2}$ and TNF- $\alpha$-induced cell death (Sakurai et al., 2006; Liu J. L. et al., 2015) and the protection of hypothermia was weakened when an ERK inhibitor was used (Sakurai et al., 2006). Moreover, increased NF- $\kappa$ B activity was observed with upregulating Cirbp, when mice were exposed to lower temperatures (Sakurai et al., 2006; Kaneko and Kibayashi, 2012). These data suggest that Cirbp protects cells from apoptosis partly through activating the NF- $\kappa \mathrm{B}$ signaling. However, the mechanism of Cirbp in hypothermia protection is still unclear and needs more studies for a better understanding.

RBM3 is also a cold-induced protein which is induced by hypothermia (Derry et al., 1995; Danno et al., 1997) and has an impact on neuroprotection against various toxic insults such as hypoxia, UV and nitric oxide (Rosenthal et al., 2017; Yang et al., 2017; Zhuang et al., 2017). One study has further discussed whether mild hypothermia and RBM3 prevents neural cells from UV irradiation-elicited apoptosis using human neuroblastoma cell line SH-SY5Y as a cell model for neural cell death (Zhuang et al., 2017). It was indicated that mild hypothermia protected SH-SY5Y cells from UV irradiation-induced apoptosis. However, the protective effect of mild hypothermia was abrogated when RBM3 was silenced. On the contrast, SHSY5Y cells could be rescued from UV-induced apoptosis when RBM3 was overexpressed. Obviously, RBM3 is the key mediator of mild hypothermia-related protection against UV in neuroblastoma cells. There is also a study evaluating whether RBM3 can inhibit staurosporine-induced apoptosis in neuronlike PC12 cells (Chip et al., 2011). Mild hypothermia profoundly promoted RBM3 expression and rescued neuronal cells from apoptosis. After blocking RBM3 expression in neuronal cells by specific siRNAs, the neuroprotective effect of hypothermia was significantly diminished, and RBM3 over-expression provided neuroprotection in the absence of hypothermia. Taken together, it is apparent that RBM3 is involved in hypothermia-induced neuroprotection. Furthermore, several studies have indicated that pro-apoptotic proteins Bax, Bad, apoptotic protein PARP and caspase- 3 are downregulated when the expression of RBM3 is increased under hypothermia, while the anti-apoptotic protein Bcl-2 is induced (Chip et al., 2011; Ferry et al., 2011; Zhu et al., 2016b; Zhuang et al., 2017). Yang et al. (2017) found that RBM3 protects neuroblastoma cells from NO-induced apoptosis by suppressing p38 signaling, which mediates apoptosis through miR-143 induction. It has been reported that RBM3 is the key mediator of mild hypothermia-related protection against UV in neuroblastoma cells, and the neuroprotective effect might be exerted through interfering with p38 and JNK pathways. Moreover, RBM3 exerts its cell-protective effects by modulating PERK-eIF2 $\alpha$-CHOP signaling (Zhou et al., 2017). The PERK-eIF2 $\alpha$-CHOP signaling pathway is one of three main branches involved in unfolded protein response (UPR) activation, and it is involved in UPR-induced apoptosis (Hetz, 2012). The effects of RBM3 on UPR-induced apoptosis have been studied. The research uncovered a hypothermia induced RBM3 expression, and that RBM3 represses the phosphorylation of PERK and eIF $2 \alpha$. CHOP expression was downregulated by phosphorylation of PERK and eIF2 $\alpha$, and EIF2 $\alpha$ phosphorylation and CHOP protein expression were elevated in human embryonic kidney HEK293 cells by specific small interfering RNAs and in hippocampal organotypic slice cultured from RBM3 knockout mice (Zhu et al., 2016b). In summary, Cirbp and RBM3 have neuroprotective effects in nerve injury and may provide a potential therapeutic target for the neuroprotection.

\section{CONCLUSION}

Hypothermia therapy has been proven neuroprotective in the patients suffering from neural injuries such as cardiac arrest and stroke, as established by many studies on the subject. However, the mechanistic aspects are not clearly understood. Clearly, more work is needed, including determination of best strategies to induce hypothermia, improving the protection and clarifying the mechanism. As discussed in this article, local hypothermia may be the best option for providing protection similar to general hypothermia and for reducing temperature effects throughout the body with minimal side effects. Several neuroprotective strategies are being tested to 
enhance hypothermia protection. Further, cold induced proteins are important in hypothermia protection. The discussion here should provide guidance for future animal studies and clinical trials on hypothermia neuroprotection.

\section{AUTHOR CONTRIBUTIONS}

Y-JS and Z-YZ prepared first draft of the manuscript. All authors edited the review article. G-YL approved the submission of the

\section{REFERENCES}

Alexander, M. L., Hill, C. A., Rosenkrantz, T. S., and Fitch, R. H. (2012). Evaluation of the therapeutic benefit of delayed administration of erythropoietin following early hypoxic-ischemic injury in rodents. Dev. Neurosci. 34, 515-524. doi: 10. $1159 / 000345645$

Aoki, M., Nomura, F., Stromski, M. E., Tsuji, M. K., Fackler, J. C., Hickey, P. R., et al. (1993). Effects of $\mathrm{pH}$ on brain energetics after hypothermic circulatory arrest. Ann. Thorac. Surg. 55, 1093-1103. doi: 10.1016/0003-4975(93)90014-9

Atici, A., Celik, Y., Gulasi, S., Turhan, A. H., Okuyaz, C., and Sungur, M. A. (2015). Comparison of selective head cooling therapy and whole body cooling therapy in newborns with hypoxic ischemic encephalopathy: short term results. Turk. Pediatr. Ars. 50, 27-36. doi: 10.5152/tpa.2015. 2167

Azzopardi, D., Brocklehurst, P., Edwards, D., Halliday, H., Levene, M., Thoresen, M., et al. (2008). The TOBY study. Whole body hypothermia for the treatment of perinatal asphyxial encephalopathy: a randomised controlled trial. BMC Pediatr. 8:17. doi: 10.1186/1471-2431-8-17

Barks, J. D., Liu, Y. Q., Shangguan, Y., and Silverstein, F. S. (2010). Phenobarbital augments hypothermic neuroprotection. Pediatr. Res. 67, 532-537. doi: 10.1203/PDR.0b013e3181d4ff4d

Bazley, F. A., Pashai, N., Kerr, C. L., and All, A. H. (2014). The effects of local and general hypothermia on temperature profiles of the central nervous system following spinal cord injury in rats. Ther. Hypothermia Temp. Manag. 4, 115-124. doi: 10.1089/ther.2014.0002

Bennet, L., Roelfsema, V., George, S., Dean, J. M., Emerald, B. S., and Gunn, A. J. (2007). The effect of cerebral hypothermia on white and grey matter injury induced by severe hypoxia in preterm fetal sheep. J. Physiol. 578(Pt 2), 491-506. doi: 10.1113/jphysiol.2006.119602

Berman, D. R., Mozurkewich, E., Liu, Y., Shangguan, Y., Barks, J. D., and Silverstein, F. S. (2013). Docosahexaenoic acid augments hypothermic neuroprotection in a neonatal rat asphyxia model. Neonatology 104, 71-78. doi: $10.1159 / 000351011$

Carraway, R., and Leeman, S. E. (1975). The synthesis of neurotensin. J. Biol. Chem. 250, 1912-1918.

Celik, Y., Atici, A., Gulasi, S., Okuyaz, C., Makharoblidze, K., and Sungur, M. A. (2016). Comparison of selective head cooling versus whole-body cooling. Pediatr. Int. 58, 27-33. doi: 10.1111/ped.12747

Chip, S., Zelmer, A., Ogunshola, O. O., Felderhoff-Mueser, U., Nitsch, C., Buhrer, C., et al. (2011). The RNA-binding protein RBM3 is involved in hypothermia induced neuroprotection. Neurobiol. Dis. 43, 388-396. doi: 10.1016/j.nbd.2011. 04.010

Clifton, G. L., Miller, E. R., Choi, S. C., Levin, H. S., McCauley, S., Smith, K. R., et al. (2001). Lack of effect of induction of hypothermia after acute brain injury. N. Engl. J. Med. 344, 556-563. doi: 10.1056/NEJM20010222344 0803

Colbourne, F., Grooms, S. Y., Zukin, R. S., Buchan, A. M., and Bennett, M. V. (2003). Hypothermia rescues hippocampal CA1 neurons and attenuates downregulation of the AMPA receptor GluR2 subunit after forebrain ischemia. Proc. Natl. Acad. Sci. U.S.A. 100, 2906-2910. doi: 10.1073/pnas.2628027100

Danno, S., Nishiyama, H., Higashitsuji, H., Yokoi, H., Xue, J. H., Itoh, K., et al. (1997). Increased transcript level of RBM3, a member of the glycine-rich RNAbinding protein family, in human cells in response to cold stress. Biochem. Biophys. Res. Commun. 236, 804-807. doi: 10.1006/bbrc.1997.7059 manuscript. All authors contributed to the writing, editing, and agreed to the submission of the manuscript.

\section{FUNDING}

The National Natural Science Foundation of China (81570864), the Norman Bethune Program of Jilin University (2012208), and the Natural Science Foundation of Jilin Province (20160101004JC and $20160414045 \mathrm{GH}$ ).

Dell'Anna, A. M., Taccone, F. S., Halenarova, K., and Citerio, G. (2014). Sedation after cardiac arrest and during therapeutic hypothermia. Minerva Anestesiol. 80, 954-962.

Derry, J. M., Kerns, J. A., and Francke, U. (1995). RBM3, a novel human gene in Xp11.23 with a putative RNA-binding domain. Hum. Mol. Genet. 4, 2307-2311. doi: $10.1093 / \mathrm{hmg} / 4.12 .2307$

Drenger, B., Parker, S. D., Frank, S. M., and Beattie, C. (1997). Changes in cerebrospinal fluid pressure and lactate concentrations during thoracoabdominal aortic aneurysm surgery. Anesthesiology 86, 41-47. doi: 10.1097/00000542-199701000-00007

Dubuc, I., Sarret, P., Labbé-Jullié, C., Botto, J. M., Honoré, E., Bourdel, E., et al. (1999). Identification of the receptor subtype involved in the analgesic effect of neurotensin. J. Neurosci. 19:503. doi: 10.1523/jneurosci.19-01-00503.1999

Dumont, R. J., Okonkwo, D. O., Verma, S., Hurlbert, R. J., Boulos, P. T., Ellegala, D. B., et al. (2001). Acute spinal cord injury, part I: pathophysiologic mechanisms. Clin. Neuropharmacol. 24, 254-264. doi: 10.1097/00002826200109000-00002

Dzieciol, M., Kacprzak, M., Goleniewska, B., and Zielinska, M. (2014). Osborn wave in patients with ST-elevation myocardial infarction undergoing mild therapeutic hypothermia after cardiac arrest. Acta Cardiol. 69, 532-540. doi: 10.2143/AC.69.5.3044880

Ehrenschwender, M., and Wajant, H. (2009). The role of FasL and Fas in health and disease. Adv. Exp. Med. Biol. 647, 64-93. doi: 10.1007/978-0-387-89520-8_5

Fang, A. Y., Gonzalez, F. F., Sheldon, R. A., and Ferriero, D. M. (2013). Effects of combination therapy using hypothermia and erythropoietin in a rat model of neonatal hypoxia-ischemia. Pediatr. Res. 73, 12-17. doi: 10.1038/pr.2012.138

Ferry, A. L., Vanderklish, P. W., and Dupont-Versteegden, E. E. (2011). Enhanced survival of skeletal muscle myoblasts in response to overexpression of cold shock protein RBM3. Am. J. Physiol. Cell Physiol. 301, C392-C402. doi: 10.1152/ ajpcell.00098.2011

Gao, X., Xie, H., Zhu, S., Yu, B., Xian, Y., Ouyang, Q., et al. (2018). The combination of human urinary kallidinogenase and mild hypothermia protects adult rats against hypoxic-ischemic encephalopathy-induced injury by promoting angiogenesis and regeneration. Front. Aging Neurosci. 10:196. doi: 10.3389/ fnagi.2018.00196

Gao, X. Y., Huang, J. O., Hu, Y. F., Gu, Y., Zhu, S. Z., Huang, K. B., et al. (2014). Combination of mild hypothermia with neuroprotectants has greater neuroprotective effects during oxygen-glucose deprivation and reoxygenationmediated neuronal injury. Sci. Rep. 4:7091. doi: 10.1038/srep07091

Ghahari, L., Safari, M., Joghataei, M. T., Mehdizadeh, M., and Soleimani, M. (2014). Effect of combination therapy using hypothermia and granulocyte colonystimulating factor in a rat transient middle cerebral artery occlusion model. Iran. Biomed. J. 18, 239-244.

Globus, M. Y., Alonso, O., Dietrich, W. D., Busto, R., and Ginsberg, M. D. (1995). Glutamate release and free radical production following brain injury: effects of posttraumatic hypothermia. J. Neurochem. 65, 1704-1711. doi: 10.1046/j.14714159.1995.65041704.x

Gröger, M., Scheuerle, A., Wagner, F., Simon, F., Matallo, J., Mccook, O., et al. (2013). Effects of pretreatment hypothermia during resuscitated porcine hemorrhagic shock. Crit. Care Med. 41, E105-E117. doi: 10.1097/CCM. 0b013e31827c0b1f

Gu, X., Wei, Z. Z., Espinera, A., Lee, J. H., Ji, X., Wei, L., et al. (2015). Pharmacologically induced hypothermia attenuates traumatic brain injury in neonatal rats. Exp. Neurol. 267, 135-142. doi: 10.1016/j.expneurol.2015.02.029 
Hakim, S. M., Ammar, M. A., and Reyad, M. S. (2018). Effect of therapeutic hypothermia on survival and neurological outcome in adults suffering cardiac arrest: a systematic review and meta-analysis. Minerva Anestesiol. 84, 720-730. doi: 10.23736/S0375-9393.18.12164-X

Hetz, C. (2012). The unfolded protein response: controlling cell fate decisions under ER stress and beyond. Nat. Rev. Mol. Cell. Biol. 13, 89-102. doi: 10.1038/ nrm 3270

Hofstetter, C., Boost, K. A., Flondor, M., Basagan-Mogol, E., Betz, C., Homann, M., et al. (2007). Anti-inflammatory effects of sevoflurane and mild hypothermia in endotoxemic rats. Acta Anaesthesiol. Scand. 51, 893-899. doi: 10.1111/j.13996576.2007.01353.x

Huang, J., Upadhyay, U. M., and Tamargo, R. J. (2006). Inflammation in stroke and focal cerebral ischemia. Surg. Neurol. 66, 232-245. doi: 10.1016/j.surneu.2005. 12.028

Huet, O., Kinirons, B., Dupic, L., Lajeunie, E., Mazoit, J. X., Benhamou, D., et al. (2007). Induced mild hypothermia reduces mortality during acute inflammation in rats. Acta Anaesthesiol. Scand. 51, 1211-1216. doi: 10.1111/j. 1399-6576.2007.01419.x

Hutchison, J. S., Ward, R. E., Lacroix, J., Hebert, P. C., Barnes, M. A., Bohn, D. J., et al. (2008). Hypothermia therapy after traumatic brain injury in children. N. Engl. J. Med. 358, 2447-2456. doi: 10.1056/NEJMoa0706930

Hwan, L. J., Ling, W., Xiaohuan, G., Zheng, W., Dix, T. A., and Shan Ping, Y. (2014). Therapeutic effects of pharmacologically induced hypothermia against traumatic brain injury in mice. J. Neurotrauma 31, 1417-1430. doi: 10.1089/ neu.2013.3251

Ikeda, K., Ikeda, T., Taniuchi, H., and Suda, S. (2012). Comparison of wholebody cooling and selective head cooling on changes in urinary 8-hydroxy-2deoxyguanosine levels in patients with global brain ischemia undergoing mild hypothermia therapy. Med. Sci. Monit. 18, CR409-CR414.

Ishikawa, T., and Marsala, M. (1999). Hypothermia prevents biphasic glutamate release and corresponding neuronal degeneration after transient spinal cord ischemia in the rat. Cell Mol. Neurobiol. 19, 199-208.

Jacobs, S. E., Morley, C. J., Inder, T. E., Stewart, M. J., Smith, K. R., McNamara, P. J., et al. (2011). Whole-body hypothermia for term and near-term newborns with hypoxic-ischemic encephalopathy: a randomized controlled trial. Arch. Pediatr. Adolesc. Med. 165, 692-700. doi: 10.1001/archpediatrics.2011.43

Jin, G., Liu, B., You, Z., Bambakidis, T., Dekker, S. E., Maxwell, J., et al. (2014). Development of a novel neuroprotective strategy: combined treatment with hypothermia and valproic acid improves survival in hypoxic hippocampal cells. Surgery 156, 221-228. doi: 10.1016/j.surg.2014.03.038

Jinka, T. R., Combs, V. M., and Drew, K. L. (2015). Translating drug-induced hibernation to therapeutic hypothermia. ACS Chem. Neurosci. 6, 899-904. doi: 10.1021/acschemneuro.5b00056

Kaneko, T., and Kibayashi, K. (2012). Mild hypothermia facilitates the expression of cold-inducible RNA-binding protein and heat shock protein 70.1 in mouse brain. Brain Res. 1466, 128-136. doi: 10.1016/j.brainres.2012.05.001

Karnatovskaia, L. V., Wartenberg, K. E., and Freeman, W. D. (2014). Therapeutic hypothermia for neuroprotection: history, mechanisms, risks, and clinical applications. Neurohospitalist 4, 153-163. doi: 10.1177/1941874413519802

Katz, L. M., Young, A., Frank, J. E., Wang, Y., and Park, K. (2004). Neurotensininduced hypothermia improves neurologic outcome after hypoxic-ischemia. Crit. Care Med. 32, 806-810. doi: 10.1097/01.ccm.0000114998.00860.fd

Kokko, K. P., Hadden, M. K., Price, K. L., Orwig, K. S., See, R. E., and Dix, T. A. (2005). In vivo behavioral effects of stable, receptor-selective neurotensin[8-13] analogues that cross the blood-brain barrier. Neuropharmacology 48, 417-425. doi: 10.1016/j.neuropharm.2004.10.008

Kuffler, D. P. (2010). Neuroprotection by hypothermia plus alkalinization of dorsal root ganglia neurons through ischemia. Ann. N. Y. Acad Sci. 1199, 158-163. doi: 10.1111/j.1749-6632.2009.05358.x

Kumura, E., Yoshimine, T., Takaoka, M., Hayakawa, T., Shiga, T., and Kosaka, H. (1996). Hypothermia suppresses nitric oxide elevation during reperfusion after focal cerebral ischemia in rats. Neurosci. Lett. 220, 45-48. doi: 10.1016/s03043940(96)13238-9

Lafuente, H., Pazos, M. R., Alvarez, A., Mohammed, N., Santos, M., Arizti, M., et al. (2016). Effects of cannabidiol and hypothermia on short-term brain damage in new-born piglets after acute hypoxia-ischemia. Front. Neurosci. 10:323. doi: $10.3389 /$ fnins.2016.00323
Lee, H. N., Ahn, S. M., and Jang, H. H. (2015). Cold-inducible RNA-binding protein, CIRP, inhibits DNA damage-induced apoptosis by regulating p53. Biochem. Biophys. Res. Commun. 464, 916-921. doi: 10.1016/j.bbrc.2015.07.066

Lee, J. E., Yoon, Y. J., Moseley, M. E., and Yenari, M. A. (2005). Reduction in levels of matrix metalloproteinases and increased expression of tissue inhibitor of metalloproteinase- 2 in response to mild hypothermia therapy in experimental stroke. J. Neurosurg. 103, 289-297. doi: 10.3171/jns.2005.103.2.0289

Lee, J. H., Wei, L., Gu, X., Won, S., Wei, Z. Z., Dix, T. A., et al. (2016). Improved therapeutic benefits by combining physical cooling with pharmacological hypothermia after severe stroke in rats. Stroke 47, 1907-1913. doi: 10.1161/ STROKEAHA.116.013061

Lee, S. H., Kim, Y. H., Kim, Y. J., and Yoon, B. W. (2008). Atorvastatin enhances hypothermia-induced neuroprotection after stroke. J. Neurol. Sci. 275, 64-68. doi: 10.1016/j.jns.2008.07.029

Leng, L. (2017). Hypothermia therapy after traumatic brain injury: a systematic review and meta-analysis. Turk. Neurosurg.

Lewen, A., Matz, P., and Chan, P. H. (2000). Free radical pathways in CNS injury. J. Neurotrauma 17, 871-890. doi: 10.1089/neu.2000.17.871

Li, S. C., Zhang, Z. W., Xue, J. H., Liu, A. J., and Zhang, H. T. (2012). Cold-inducible RNA binding protein inhibits $\mathrm{H} 2 \mathrm{O} 2$-induced apoptosis in rat cortical neurons. Brain Res. 1441, 47-52. doi: 10.1016/j.brainres.2011.12.053

Liu, J. L., Xue, J. H., Zhang, H. T., Li, S. C., Liu, Y. X., Xu, D. G., et al. (2015). Cloning, expression, and purification of cold inducible RNA-binding protein and its neuroprotective mechanism of action. Brain Res. 1597, 189-195. doi: 10.1016/j.brainres.2014.11.061

Liu, S., Geng, X., Forreider, B., Xiao, Y., Kong, Q., Ding, Y., et al. (2015). Enhanced beneficial effects of mild hypothermia by phenothiazine drugs in stroke therapy. Neurol. Res. 37, 454-460. doi: 10.1179/1743132815Y.0000000031

Liu, L., Kim, J. Y., Koike, M. A., Yoon, Y. J., Tang, X. N., Ma, H., et al. (2008). FasL shedding is reduced by hypothermia in experimental stroke. J. Neurochem. 106, 541-550. doi: 10.1111/j.1471-4159.2008.05411.x

Liu, Y., Shangguan, Y., Barks, J. D., and Silverstein, F. S. (2012). Bumetanide augments the neuroprotective efficacy of phenobarbital plus hypothermia in a neonatal hypoxia-ischemia model. Pediatr. Res. 71, 559-565. doi: 10.1038/pr. 2012.7

Liu, Y. C., Lee, Y. D., Wang, H. L., Liao, K. H., Chen, K. B., Poon, K. S., et al. (2017). Anesthesia-induced hypothermia attenuates early-phase blood-brain barrier disruption but not infarct volume following cerebral ischemia. PLoS One 12:e0170682. doi: 10.1371/journal.pone.0170682

Lv, H. Y., Wu, S. J., Wang, Q. L., Yang, L. H., Ren, P. S., Qiao, B. J., et al. (2017). Effect of erythropoietin combined with hypothermia on serum tau protein levels and neurodevelopmental outcome in neonates with hypoxic-ischemic encephalopathy. Neural Regen. Res. 12, 1655-1663. doi: 10.4103/1673-5374. 217338

Ma, D., Hossain, M., Chow, A., Arshad, M., Battson, R. M., Sanders, R. D., et al. (2005). Xenon and hypothermia combine to provide neuroprotection from neonatal asphyxia. Ann. Neurol. 58, 182-193. doi: 10.1002/ana.20547

Maekawa, T., Yamashita, S., Nagao, S., Hayashi, N., Ohashi, Y., and BrainHypothermia Study, G. (2015). Prolonged mild therapeutic hypothermia versus fever control with tight hemodynamic monitoring and slow rewarming in patients with severe traumatic brain injury: a randomized controlled trial. J. Neurotrauma 32, 422-429. doi: 10.1089/neu.2013.3197

Mazzone, G. L., and Nistri, A. (2011). Electrochemical detection of endogenous glutamate release from rat spinal cord organotypic slices as a real-time method to monitor excitotoxicity. J. Neurosci. Methods 197, 128-132. doi: 10.1016/j. jneumeth.2011.01.033

Mohr, J., Ruchholtz, S., Hildebrand, F., Flohé, S., Frink, M., Witte, I., et al. (2013). Induced hypothermia does not impair coagulation system in a swine multiple trauma model. J. Trauma Acute Care Surg. 74, 1014-1020. doi: 10.1097/ta. 0b013e3182826edd

Nilupul Perera, M., Ma, H. K., Arakawa, S., Howells, D. W., Markus, R., Rowe, C. C., et al. (2006). Inflammation following stroke. J. Clin. Neurosci. 13, 1-8. doi: 10.1016/j.jocn.2005.07.005

Nishiyama, H., Itoh, K., Kaneko, Y., Kishishita, M., Yoshida, O., and Fujita, J. (1997). A glycine-rich RNA-binding protein mediating cold-inducible suppression of mammalian cell growth. J. Cell Biol. 137, 899-908. doi: 10.1083/ jcb.137.4.899 
Oda, Y., Gao, G., Wei, E. P., and Povlishock, J. T. (2011). Combinational therapy using hypothermia and the immunophilin ligand FK506 to target altered pial arteriolar reactivity, axonal damage, and blood-brain barrier dysfunction after traumatic brain injury in rat. J. Cereb. Blood Flow Metab. 31, 1143-1154. doi: $10.1038 /$ jcbfm.2010.208

Oh, J. S., Tulasi, J., Xiaodan, R., Stacey, W. C., and Neumar, R. W. (2017). Valproic acid combined with postcardiac arrest hypothermic-targeted temperature management prevents delayed seizures and improves survival in a rat cardiac arrest model. Crit. Care Med. 45, e1149-e1156. doi: 10.1097/CCM. 0000000000002690

Ohmura, A., Nakajima, W., Ishida, A., Yasuoka, N., Kawamura, M., Miura, S., et al. (2005). Prolonged hypothermia protects neonatal rat brain against hypoxicischemia by reducing both apoptosis and necrosis. Brain Dev. 27, 517-526. doi: 10.1016/j.braindev.2005.01.004

Ok, J. H., Kim, Y. H., and Ha, K. Y. (2012). Neuroprotective effects of hypothermia after spinal cord injury in rats: comparative study between epidural hypothermia and systemic hypothermia. Spine 37, E1551-E1559. doi: 10.1097/BRS.0b013e31826ff7f1

Park, E., Velumian, A. A., and Fehlings, M. G. (2004). The role of excitotoxicity in secondary mechanisms of spinal cord injury: a review with an emphasis on the implications for white matter degeneration. J. Neurotrauma 21, 754-774. doi: 10.1089/0897715041269641

Park, J. S., Park, S. J., Peng, X. D., Wang, M., Yu, M. A., and Lee, S. H. (1999). Involvement of DNA-dependent protein kinase in UV-induced replication arrest. J. Biol. Chem. 274, 32520-32527. doi: 10.1074/jbc.274.45.32520

Park, W. S., Sung, S. I., Ahn, S. Y., Yoo, H. S., Sung, D. K., Im, G. H., et al. (2015). Hypothermia augments neuroprotective activity of mesenchymal stem cells for neonatal hypoxic-ischemic encephalopathy. PLoS One 10:e0120893. doi: 10.1371/journal.pone.0120893

Piehl, S., Hoefig, C. S., Scanlan, T. S., and Kohrle, J. (2011). Thyronamines-past, present, and future. Endocr. Rev. 32, 64-80. doi: 10.1210/er.2009-0040

Plesnila, N., Zinkel, S., Le, D. A., Amin-Hanjani, S., Wu, Y., Qiu, J., et al. (2001). BID mediates neuronal cell death after oxygen/ glucose deprivation and focal cerebral ischemia. Proc. Natl. Acad. Sci. U.S.A. 98, 15318-15323. doi: 10.1073/ pnas. 261323298

Powell, E., Faulkner, S., Bainbridge, A., Kereyni, A., Kelen, D., Chandrasekaran, M., et al. (2011). Improved neuroprotection with melatonin-augmented hypothermia vs hypothermia alone in a perinatal asphyxia model: a randomized study. Pediatr. Res. 96:67. doi: 10.1038/pr.2011.292

Robertson, N. J., Faulkner, S., Fleiss, B., Bainbridge, A., Andorka, C., Price, D., et al. (2013). Melatonin augments hypothermic neuroprotection in a perinatal asphyxia model. Brain 136(Pt 1), 90-105. doi: 10.1093/brain/aws285

Rocha-Ferreira, E., Poupon, L., Zelco, A., Leverin, A. L., Nair, S., Jonsdotter, A., et al. (2018). Neuroprotective exendin-4 enhances hypothermia therapy in a model of hypoxic-ischaemic encephalopathy. Brain 141, 2925-2942. doi: 10.1093/brain/awy220

Rosenthal, L. M., Tong, G., Walker, C., Wowro, S. J., Krech, J., Pfitzer, C., et al. (2017). Neuroprotection via RNA-binding protein RBM3 expression is regulated by hypothermia but not by hypoxia in human SK-N-SH neurons. Hypoxia 5, 33-43. doi: 10.2147/HP.S132462

Rutherford, M. A., Azzopardi, D., Whitelaw, A., Cowan, F., Renowden, S., Edwards, A. D., et al. (2005). Mild hypothermia and the distribution of cerebral lesions in neonates with hypoxic-ischemic encephalopathy. Pediatrics 116, 1001-1006. doi: 10.1542/peds.2005-0328

Sahara, T., Goda, T., and Ohgiya, S. (2002). Comprehensive expression analysis of time-dependent genetic responses in yeast cells to low temperature. J. Biol. Chem. 277, 50015-50021. doi: 10.1074/jbc.M209258200

Sahin, S., Alkan, T., Temel, S. G., Tureyen, K., Tolunay, S., and Korfali, E. (2010). Effects of citicoline used alone and in combination with mild hypothermia on apoptosis induced by focal cerebral ischemia in rats. J. Clin. Neurosci. 17, 227-231. doi: 10.1016/j.jocn.2009.05.016

Sahuquillo, J., and Vilalta, A. (2007). Cooling the injured brain: how does moderate hypothermia influence the pathophysiology of traumatic brain injury. Curr. Pharm. Des. 13, 2310-2322. doi: 10.2174/13816120778136 8756

Sakurai, T., Itoh, K., Higashitsuji, H., Nonoguchi, K., Liu, Y., Watanabe, H., et al. (2006). Cirp protects against tumor necrosis factor- $\alpha$-induced apoptosis via activation of extracellular signal-regulated kinase. Biochim. Biophys. Acta 1763, 290-295. doi: 10.1016/j.bbamcr.2006.02.007

Sarkar, S., Barks, J. D., Bhagat, I., Dechert, R., and Donn, S. M. (2009a). Pulmonary dysfunction and therapeutic hypothermia in asphyxiated newborns: whole body versus selective head cooling. Am. J. Perinatol. 26, 265-270. doi: 10.1055/s0028-1103154

Sarkar, S., Barks, J. D., Bhagat, I., and Donn, S. M. (2009b). Effects of therapeutic hypothermia on multiorgan dysfunction in asphyxiated newborns: whole-body cooling versus selective head cooling. J. Perinatol. 29, 558-563. doi: 10.1038/jp. 2009.37

Schaller, B., and Graf, R. (2003). Hypothermia and stroke: the pathophysiological background. Pathophysiology 10, 7-35. doi: 10.1016/j.pathophys.2003.09.001

Schwab, S., Schwarz, S., Spranger, M., Keller, E., Bertram, M., Hacke, W., et al. (1998). Moderate Hypothermia in the Treatment of Patients with Severe Middle Cerebral Artery Infarction. Vienna: Springer.

Shamas-Din, A., Brahmbhatt, H., Leber, B., and Andrews, D. W. (2011). BH3only proteins: orchestrators of apoptosis. Biochim. Biophys. Acta 1813, 508-520. doi: 10.1016/j.bbamcr.2010.11.024

Shankaran, S., Laptook, A. R., Ehrenkranz, R. A., Tyson, J. E., McDonald, S. A., Donovan, E. F., et al. (2005). Whole-body hypothermia for neonates with hypoxic-ischemic encephalopathy. N. Engl. J. Med. 353, 1574-1584. doi: 10. 1056/NEJMcps050929

Smith, K. E., Boules, M., Williams, K., Fauq, A. H., and Richelson, E. (2011). The role of NTS2 in the development of tolerance to NT69L in mouse models for hypothermia and thermal analgesia. Behav. Brain Res. 224, 344-349. doi: 10.1016/j.bbr.2011.06.014

Stuart, E., Shaun, M., Durmus, D., and David, H. (2013). Is cold acclimation of benefit to hibernating rodents? J. Exp. Biol. 216, 2140-2149. doi: 10.1242/jeb. 079160

Sun, Y. J., Ma, S., Fan, B., Wang, Y., Wang, S. R., and Li, G. Y. (2019). Therapeutic hypothermia protects photoreceptors through activating Cirbp pathway. Neurochem. Int. 126, 86-95. doi: 10.1016/j.neuint.2019. 03.006

Thundyil, J., Pavlovski, D., Hsieh, Y. H., Gelderblom, M., Magnus, T., Fairlie, D. P., et al. (2012). C5a receptor (CD88) inhibition improves hypothermia-induced neuroprotection in an in vitro ischemic model. Neuromol. Med. 14, 30-39. doi: 10.1007/s12017-012-8167-0

Tu, Y., Chen, C., Sun, H. T., Cheng, S. X., Liu, X. Z., Qu, Y., et al. (2012). Combination of temperature-sensitive stem cells and mild hypothermia: a new potential therapy for severe traumatic brain injury. J. Neurotrauma 29, 2393-2403. doi: 10.1089/neu.2012.2374

Tu, Y., Miao, X. M., Yi, T. L., Chen, X. Y., Sun, H. T., Cheng, S. X., et al. (2016). Neuroprotective effects of bloodletting at jing points combined with mild induced hypothermia in acute severe traumatic brain injury. Neural Regen. Res. 11, 931-936. doi: 10.4103/1673-5374.184491

Tyler-McMahon, B. M., Boules, M., and Richelson, E. (2000a). Neurotensin: peptide for the next millennium. Regul. Pept. 93, 125-136. doi: 10.1016/s01670115(00)00183-x

Tyler-McMahon, B. M., Stewart, J. A., Farinas, F., McCormick, D. J., and Richelson, E. (2000b). Highly potent neurotensin analog that causes hypothermia and antinociception. Eur. J. Pharmacol. 390, 107-111. doi: 10.1016/s0014-2999(99) 00877-8

Vishwakarma, S. K., Bardia, A., Chandrakala, L., Arshiya, S., Paspala, S. A. B., Satti, V., et al. (2017). Enhanced neuroprotective effect of mild-hypothermia with VPA against ethanol-mediated neuronal injury. Tissue Cell 49, 638-647. doi: 10.1016/j.tice.2017.09.004

Vitkovic, L., Maeda, S., and Sternberg, E. (2001). Anti-inflammatory cytokines: expression and action in the brain. Neuroimmunomodulation 9, 295-312. doi: $10.1159 / 000059387$

Wang, D., Liang, J., Zhang, J., Liu, S., and Sun, W. (2014). Mild hypothermia combined with a scaffold of NgR-silenced neural stem cells/Schwann cells to treat spinal cord injury. Neural Regen. Res. 9, 2189-2196. doi: 10.4103/16735374.147952

Wang, L., Jiang, F., Li, Q., He, X., and Ma, J. (2014). Mild hypothermia combined with neural stem cell transplantation for hypoxic-ischemic encephalopathy: neuroprotective effects of combined therapy. Neural Regen. Res. 9, 1745-1752. doi: $10.4103 / 1673-5374.143417$ 
Wang, D., and Zhang, J. (2015). Effects of hypothermia combined with neural stem cell transplantation on recovery of neurological function in rats with spinal cord injury. Mol. Med. Rep. 11, 1759-1767. doi: 10.3892/mmr.2014.2905

Wang, H., Olivero, W., Lanzino, G., Elkins, W., Rose, J., Honings, D., et al. (2004). Rapid and selective cerebral hypothermia achieved using a cooling helmet. J. Neurosurg. 100, 272-277. doi: 10.3171/jns.2004.100.2.0272

Wang, H., Olivero, W., Wang, D., and Lanzino, G. (2006). Cold as a therapeutic agent. Acta Neurochir. 148, 565-570. doi: 10.1007/s00701-006-0747-z

Wang, Q., Li, A. L., Zhi, D. S., and Huang, H. L. (2007). Effect of mild hypothermia on glucose metabolism and glycerol of brain tissue in patients with severe traumatic brain injury. Chin. J. Traumatol. 10, 246-249.

Whittington, R. A., Bretteville, A., Virag, L., Emala, C. W., Maurin, T. O., Marcouiller, F., et al. (2013). Anesthesia-induced hypothermia mediates decreased ARC gene and protein expression through ERK/MAPK inactivation. Sci. Rep. 3:1388. doi: 10.1038/srep01388

Wowk, S., Ma, Y., and Colbourne, F. (2014). Mild therapeutic hypothermia does not reduce thrombin-induced brain injury. Ther. Hypothermia Temp. Manag. 4, 180-187. doi: 10.1089/ther.2014.0014

Wu, M. J., Zhang, Y. J., Yu, H., and Liu, B. (2017). Emulsified isoflurane combined with therapeutic hypothermia improves survival and neurological outcomes in a rat model of cardiac arrest. Exp. Ther. Med. 13, 891-898. doi: 10.3892/etm. 2017.4044

Xia, Z., Jiang, K., Liu, T., Zheng, H., Liu, X., and Zheng, X. (2013). The protective effect of cold-inducible rna-binding protein (CIRP) on testicular torsion/detorsion: an experimental study in mice. J. Pediatr. Surg. 48, 2140-2147. doi: 10.1016/j.jpedsurg.2013.02.065

Xu, S. Y., Hu, F. Y., Ren, L. J., Chen, L., Zhou, Z. Q., Zhang, X. J., et al. (2015). Dantrolene enhances the protective effect of hypothermia on cerebral cortex neurons. Neural Regen. Res. 10, 1279-1285. doi: 10.4103/1673-5374.162761

Xue, J. H., Nonoguchi, K., Fukumoto, M., Sato, T., Nishiyama, H., Higashitsuji, H., et al. (1999). Effects of ischemia and H2O2 on the cold stress protein CIRP expression in rat neuronal cells. Free Radic. Biol. Med. 27, 1238-1244. doi: 10.1016/s0891-5849(99)00158-6

Yang, H. J., Ju, F., Guo, X. X., Ma, S. P., Wang, L., Cheng, B. F., et al. (2017). RNA-binding protein RBM3 prevents NO-induced apoptosis in human neuroblastoma cells by modulating p38 signaling and miR-143. Sci. Rep. 7:41738. doi: $10.1038 /$ srep41738

Yatsiv, I., Morganti-Kossmann, M. C., Perez, D., Dinarello, C. A., Novick, D., Rubinstein, M., et al. (2002). Elevated intracranial IL-18 in humans and mice after traumatic brain injury and evidence of neuroprotective effects of IL-18binding protein after experimental closed head injury. J. Cereb. Blood Flow Metab. 22, 971-978. doi: 10.1097/00004647-200208000-00008

Yenari, M. A., Iwayama, S., Cheng, D., Sun, G. H., Fujimura, M., Morita-Fujimura, Y., et al. (2002). Mild hypothermia attenuates cytochrome $\mathrm{c}$ release but does not alter Bcl-2 expression or caspase activation after experimental stroke. J. Cereb. Blood Flow Metab. 22, 29-38. doi: 10.1097/00004647-200201000-00004

Yokomizo, A., Ono, M., Nanri, H., Makino, Y., Ohga, T., Wada, M., et al. (1995). Cellular levels of thioredoxin associated with drug sensitivity to cisplatin, mitomycin c, doxorubicin, and etoposide. Cancer Res. 55, 4293-4296.

Yum, S. K., Seo, Y. M., Kwun, Y., Moon, C. J., Youn, Y. A., and Sung, I. K. (2018). Therapeutic hypothermia in infants with hypoxic-ischemic encephalopathy and reversible persistent pulmonary hypertension: short-term hospital outcomes. J. Matern. Fetal Neonatal Med. 31, 3108-3114. doi: 10.1080/14767058.2017. 1365123
Zhang, J., Liu, K., Elmadhoun, O., Ji, X., Duan, Y., Shi, J., et al. (2018). Synergistically induced hypothermia and enhanced neuroprotection by pharmacological and physical approaches in stroke. Aging Dis. 9, 578-589. doi: 10.14336/AD.2017.0817

Zhang, Z., Zhang, L., Ding, Y., Han, Z., and Ji, X. (2018). Effects of therapeutic hypothermia combined with other neuroprotective strategies on ischemic stroke: review of evidence. Aging Dis. 9, 507-522. doi: 10.14336/AD.2017.0628

Zhang, M., Wang, H., Zhao, J., Chen, C., Leak, R. K., Xu, Y., et al. (2013). Drug-induced hypothermia in stroke models: does it always protect? CNS Neurol. Disord. Drug Targets 12, 371-380. doi: 10.2174/187152731131203 0010

Zhao, K., Li, R., Bi, S., Li, Y., Liu, L., Jia, Y. L., et al. (2018). Combination of mild therapeutic hypothermia and adipose-derived stem cells for ischemic brain injury. Neural Regen. Res. 13, 1759-1770. doi: 10.4103/1673-5374.23 8617

Zhou, R. B., Lu, X. L., Zhang, C. Y., and Yin, D. C. (2017). RNA binding motif protein 3: a potential biomarker in cancer and therapeutic target in neuroprotection. Oncotarget 8, 22235-22250. doi: 10.18632/oncotarget. 14755

Zhu, C., Wang, X., Cheng, X., Qiu, L., Xu, F., Simbruner, G., et al. (2004). Postischemic hypothermia-induced tissue protection and diminished apoptosis after neonatal cerebral hypoxia-ischemia. Brain Res. 996, 67-75. doi: 10.1016/j. brainres.2003.10.013

Zhu, H., Meloni, B. P., Bojarski, C., Knuckey, M. W., and Knuckey, N. W. (2005). Post-ischemic modest hypothermia ( 35 degrees $\mathrm{C}$ ) combined with intravenous magnesium is more effective at reducing CA1 neuronal death than either treatment used alone following global cerebral ischemia in rats. Exp. Neurol. 193, 361-368. doi: 10.1016/j.expneurol.2005.01.022

Zhu, J., Wang, B., Lee, J. H., Armstrong, J. S., Kulikowicz, E., Bhalala, U. S., et al. (2015). Additive neuroprotection of a 20-hete inhibitor with delayed therapeutic hypothermia after hypoxia-ischemia in neonatal piglets. Dev. Neurosci. 37, 376-389. doi: 10.1159/000369007

Zhu, X., Bührer, C., and Wellmann, S. (2016a). Cold-inducible proteins CIRP and RBM3, a unique couple with activities far beyond the cold. Cell. Mol. Life Sci. 73, 3839-3859. doi: 10.1007/s00018-016-2253-7

Zhu, X., Zelmer, A., Kapfhammer, J. P., and Wellmann, S. (2016b). Coldinducible RBM3 inhibits PERK phosphorylation through cooperation with NF90 to protect cells from endoplasmic reticulum stress. FASEB J. 30, 624-634. doi: 10.1096/fj.15-274639

Zhuang, R. J., Ma, J., Shi, X., Ju, F., Ma, S. P., Wang, L., et al. (2017). Cold-inducible protein RBM3 Protects UV irradiation-induced apoptosis in neuroblastoma cells by affecting p38 and JNK pathways and $\mathrm{Bcl} 2$ family proteins. J. Mol. Neurosci. 63, 142-151. doi: 10.1007/s12031-017-0964-3

Conflict of Interest Statement: The authors declare that the research was conducted in the absence of any commercial or financial relationships that could be construed as a potential conflict of interest.

Copyright (c) 2019 Sun, Zhang, Fan and Li. This is an open-access article distributed under the terms of the Creative Commons Attribution License (CC BY). The use, distribution or reproduction in other forums is permitted, provided the original author(s) and the copyright owner(s) are credited and that the original publication in this journal is cited, in accordance with accepted academic practice. No use, distribution or reproduction is permitted which does not comply with these terms. 